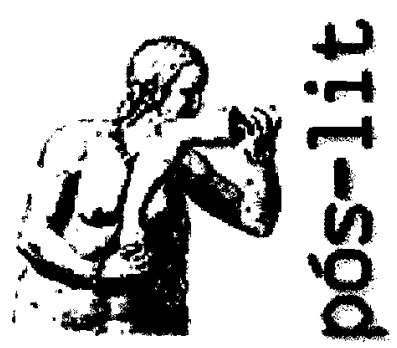

Programa de Pós-Graduação em Letras: Estudos Literários da Faculdade de Letras da UFMG

Artigo disponível em http://www.letras.ufmg.br/poslit

\section{POÉTICAS DA LUCIDEZ : NOTAS SOBRE OS POETAS-CRÍTICOS DA MODERNIDADE}

Maria Esther Maciel

UFMG

Dans cet essai je cherche étudier la tradition des poètes-critiques modernes, ayant comme but pas seulement la diversité contradictoire des poèmes et de la production théorique de ces auteurs, mais aussi identifier les possibles traits capables d'atribuer à la critique faite à partir de la création poétique une specificité par rapport à la critique faite par des non-poètes. J'essaie de montrer encore comme ces poètes se sont tournés vers leur temps, théorisant la Modernité et en composant - par des chemins inconnus une histoire sélective et pas linéaire de la poésie moderne. 

queue.

“... S'accoutumer à penser en Serpent qui s'avale par la Car c'est toute la question. Je "contiens" ce qui me "contient". Et je suis successivement contenant et contenu."

Paul Valéry

Seduzidos pelas construções da razão crítica, muitos poetas modernos converteram a poesia em espaço de reflexão crítica e de debate sobre si mesma, propondo-se também a suplementar o trabalho criativo através de textos teóricos sobre questões pertinentes ao fazer literário, ensaios sobre outros autores e outras obras que lhes são afins, bem como reflexões mais generalizadas sobre a poesia e a cultura do seu tempo e do passado.

Pode-se dizer que essa prática, fundada na aliança explícita entre criação e reflexão, marcou pelo menos a metade da história da poesia moderna ocidental e ainda vigora, com outros matizes, no cenário crítico contemporâneo, remontando inegavelmente a uma das vertentes poderosas do Romantismo: a dos alemães de Jena, em fins do sec. XVIII.

Reunidos em torno da revista-manifesto "Athenaeum", os poetas Novalis, August e Friedrich Schlegel inauguraram um modelo poético não menos contraditório que inovador, que tinha como princípio básico a auto-reflexão. Digo contraditório porque os românticos, empenhados na conquista de uma "universalidade progressiva", puseram a poesia em contato com a filosofia e a religião, além de buscarem a conjunção entre poesia e prosa, inspiração e crítica, poesia de arte e poesia da natureza, arte e vida, literatura e sociedade. À exigência do rigor intelectual aliaram a sagrada espontaneidade da poesia e à teoria da criatividade poética, os exercícios transcendentais.

Mas à parte o gosto acentuado dos poetas românticos pelo sagrado e pelos vôos da imaginação, do qual não me ocuparei especificamente neste ensaio, pelo menos num primeiro momento eles privilegiaram a consciência poética em detrimento da espontaneidade e da inspiração.
Conforme assinala Maurice Blanchot a propósito da "febre intelectual" que contagiou os primeiros românticos e conduziu a poesia ao território da lucidez crítica, "o romantismo é excessivo, mas seu primeiro excesso é um excesso de pensamento."

Walter Benjamin , em sua tese sobre o conceito de crítica de arte no romantismo alemão, observa, cuidadosamente, que as palavras "crítica" e "crítico" são as mais recorrentes nos escritos dos poetas do Athenaeum. Crítica, no sentido de "experimento na obra de arte, através do qual a reflexão desta é despertada e ela é levada à consciência e ao conhecimento de si mesma"'. O que significa que, à medida que a poesia é consciência, a consciência da poesia passa a ser também poesia.

A ironia, tal como foi concebida pelos românticos, torna-se um conceito fundamental dentro desse processo: nāo mais entendida como um mero recurso de retórica, mas sistematizada enquanto um sofisticado artifício literário, ela permite ao poeta distanciar-se criticamente de sua obra e ao mesmo tempo nesta introduzir o seu ato de distanciamento, possibilitando, assim, não apenas a disjunção entre sujeito poético e sujeito empírico, como também a relação dialógica entre exame crítico e criação poética.

Caracterizada por Schlegel como uma "beleza lógica", por resultar, como elucidou Victor-Pierre Stirniman, "de um juízo reflexivo que tem por objeto o próprio refletir, portanto da reflexão estética sobre o próprio sujeito que reflete" ${ }^{\prime \prime}$ a ironia define o sujeito cindido pela consciência de sua própria cisão.

Esse conceito, posteriormente redimensionado à luz das teorias poéticas do século $\mathrm{XX}$, sob o nome de metalinguagem, pode ser considerado - enquanto primeira tentativa de se evidenciar teoricamente o descentramento do "eu" poético e a crise da idéia de literatura como representação - uma das grandes contribuiçōes do primeiro romantismo para a formação da poesia e da crítica modernas.

Esse romantismo, designado por Haroldo de Campos como "intrínseco", em contraposição ao romantismo declamatório e sentimental

4. CAMPOS, 1985, p.25. 
que vigorou em muitos países do Ocidente ${ }^{4}$, inclui também poetas como Wordsworth e Coleridge, na Inglaterra, e Edgar Allan Poe, nos Estados Unidos, dentre outros. O que não significa, entretanto, que outros poetas anteriores não tivessem se dedicado ao exercício da reflexão dentro ou a partir da poesia que faziam.

Em Dante, por exemplo, coexistiram o criador, o teórico da linguagem e o pensador político. Camões exerceu com maestria a metalinguagem em muitos dos seus poemas, e Horácio foi, além de poeta, um eminente teórico da poesia clássica. Não podemos nos esquecer também de autores que antecederam imediatamente o advento do romantismo alemão, como Schiller e Goethe. Neste último encontramos o modelo mais completo de poeta-pensador que, afeito ao entrecruzamento de diferentes campos do conhecimento, compôs uma obra enciclopédica, onde a práxis poética convive com uma ampla reflexão sobre temas universais. Ele pode ser inclusive considerado - a despeito de suas particularidades - precursor de um ramo que, dentro da tradição ocidental de poetas-críticos, define a postura interdisciplinar de muitos escritores desta segunda metade do século XX, como por exemplo, Octavio Paz. Só que, à diferença deste e dos demais, Dante e os outros antecessores ainda estavam comprometidos com todo um sistema metafísico clássico e/ou cristão, sustentado na busca da verdade e da totalidade, representadas por Deus ou pela Razão. Neles, o sujeito poético ainda estava longe de ser relativizado ou descentrado e a linguagem poética ainda não tinha conquistado a sua autonomia.

De qualquer forma, esses exercícios da lucidez realizados esparsamente em momentos anteriores ao movimento romântico prepararam o terreno para que, a partir dos últimos anos do século XVIII, a razão crítica se transformasse numa prática apaixonada. Se no período clássico, como diz Octavio Paz, a crítica tinha como fim chegar à verdade, na era moderna a verdade passa a ser crítica, crítica inclusive de si mesma. ${ }^{5}$

A partir dessas mudanças, a linguagem - com seus mecanismos de construção e desconstrução - converteu-se, para grande parte dos poetas modernos, no cerne da experiência poética e passou a ser compreendida enquanto um universo múltiplo e autônomo: a poesia foi submetida a um processo de desreferencialização e assumiu a tarefa de se auto-dizer, desmitificando, assim, a idéia de literatura como mímese da realidade.
Acrescente-se que essa autonomia do universo poético, que conferiu à palavra tanto uma soberania em relação aos dados da realidade quanto um poder de auto-crítica, não indicia, entretanto, um alheamento do poeta em relação à realidade e à história. Como atesta Octavio $\mathrm{Paz}$, "la crítica del lenguaje es la forma más radical y virulenta de la crítica de la realidad" ". Daí a consciência crítica dos poetas modernos, ao revolucionar o conceito de criação, não ter deixado também de pôr sob suspeição os valores e as certezas do mundo moderno.

É importante frisar que essa nova atitude poética frente à linguagem não se expandiu ao longo do século XIX em ritmo de continuidade. Às conquistas dos primeiros românticos alemães e ingleses se sobrepôs um outro romantismo, o chamado "extrínseco", de origem francesa e que, não obstante tenha tido um forte caráter de rebeldia frente à sociedade e aos dogmas do pensamento clássico, foi bem diferente do primeiro, no que concerne às questôes do sujeito poético e da representação. Esse romantismo, assumindo um caráter marcadamente idealista e sentimentalista, foi o que se alastrou com mais intensidade no Ocidente, predominando inclusive nos países da América Latina.

É a partir de Baudelaire que a conjunção poesia-crítica anunciada pelos primeiros românticos se consuma, evidenciando o surgimento efetivo da poesia moderna e a crise dos valores metafísicos que marcaram a corrente idealista do Romantismo. Ao culto do significado e das profundezas subjetivas, sobrepōem-se a valorização dos aspectos materiais da palavra e o destronamento da ilusória plenitude do "eu" poético.

Assim, à feição dos românticos alemães (e ingleses), os poetas modernos após Baudelaire, para justificarem sua ousada postura de reverência amorosa à linguagem, incumbiram-se de elaborar e teorizar um novo conceito de poesia. A partir deste e dos movimentos anteriores, surgiram, além do poema-crítico, textos críticos em prosa, sob a forma de ensaios, manifestos, fragmentos, cartas e depoimentos, que, do Romantismo até hoje, precedem, acompanham ou elucidam as obras poéticas de seus autores. 
O poema-crítico, enquanto modalidade poética que assume explicitamente o papel de se questionar a si mesma, resplandeceu no simbolismo francês e experimentou sua maior radicalidade com Mallarmé, tornando-se uma prática textual bastante disseminada entre os poetas de vanguarda do início deste século.

Podendo ser definido, inicialmente, como uma construção onde se manifesta a fusão das funções poética e metalingüística da linguagem, tal como as formulou Jakobson, o poema-crítico distingue-se não só por exibir sua materialidade enquanto produto engenhoso da consciência lúcida do poeta, como também por promover a sondagem de sua própria arquitetura à medida que vai se construindo. Com isso, leva às últimas conseqüências a máxima de Schlegel segundo a qual cabe à poesia "descrever a si mesma, sendo sempre simultaneamente poesia e poesia da poesia"'.

Em decorrência dessa auto-referencialidade, a linguagem geralmente assume, nessa modalidade poética, a condição de sujeito, considerando-se que a subjetividade do poeta se desloca para o poema, dando a impressão de que este se faz e se diz simultaneamente. Ou, como explica Blanchot, "a fala poética deixa de ser fala de uma pessoa: nela, ninguém fala e o que fala não é ninguém, mas parece que somente a fala se fala" $^{8}$. O que significa que, ao escrever o poema, o poeta-crítico o faz consciente de que sua voz silencia para que a linguagem possa dizer por e apesar dele, por saber que, se é pela linguagem que o sujeito se constitui, é também nela que este se perde enquanto pessoa: o próprio texto o despoja de sua pessoalidade.

Nesse movimento de explorar radicalmente a sua auto-suficiência enquanto linguagem despessoalizada, o poema-crítico acabou também assumindo, em certos momentos, a intrigante tarefa de se autodestruir criativamente, de pulverizar sua própria construção, num gesto que Barthes caracterizou muito bem como "jogo perigoso com a própria morte, (...) como aquela heroína raciniana que morre de se conhecer mas vive de se procurar." A criação poética, nesse caso, passa a se evidenciar a partir do

7. SCHLEGEL in CHIAMPI, 1992. p.62

8. 8LANCHOT, 1987. Р.35.

9. 8ARTHES, 1982. p.28. estilhaçamento que a linguagem realiza de si mesma.

Essa "autodestruição criadora", empreendida sobretudo a partir do "Un coup de dés", teve, como uma de suas funções radicais, revelar ao poema o avesso da linguagem, ou seja, o silêncio, materializado em lacunas, pausas e brancos espalhados ao redor das palavras. Se, como diz George Steiner, "onde cessa a palavra do poeta começa uma grande luz"10, foi, seduzidos por esse clarão, que poetas como Mallarmé optaram pela atomização da sintaxe e pela valorização do espaço em branco da página lugar onde o não-lugar da palavra se revela.

Luís Costa Lima, ao tratar das particularidades da poesia mallarmeana, conferiu a esse movimento de auto-negação criadora da linguagem o nome de "transcendência vazia", que, segundo o crítico, significa que "ao poema cabe mostrar como a linguagem transcende o seu uso e como esta transcendência não diz outra coisa senão da destruição que a alimenta."ll

Daí pode-se depreender que não resta ao poeta-crítico, consciente desse ponto extremo a que chegou a sua vertiginosa busca da lucidez, senão vislumbrar o abismo. E foi exatamente o fascínio pelo abismo que motivou Mallarmé a ultrapassar os limites da linguagem poética e a confessar que, à diferença de Dante, a destruição foi sua Beatriz.

Mas é necessário lembrar que nem todos os poemas-críticos encerram a vocação suicida do poema mallarmeano. Embora impulsionados pelo movimento de negação que os define como críticos, vários poemas que exploram explicitamente a metalinguagem evidenciam a sua criticidade também na defesa que fazem da criação poética e na busca de sua própria sobrevivência numa sociedade em que o poeta se sente minimizado e condenado ao desterro. Mesmo o poema de Mallarmé não escapa de ser também uma desesperada e paradoxal defesa da poesia.

A experiência de abandono vivida por Baudelaire em meio às hostilidades e o esplendor da sociedade burguesa do século XIX atesta e exemplifica bem a condição atópica do poeta na vida moderna. Em errância, oscilando entre o mudo fascínio ante o progresso que o obriga a viver nos subsolos da história e a insubmissão aos princípios que fundamentam a sociedade, resta-lhe buscar na poesia, convertida em um universo independente, as armas contra os preceitos do mundo burguês, bem como
10. STEFER, 1988. P.59 
transformá-la num refúgio para sua excêntrica condição de poeta.

Essa defesa fizeram também todos os poetas-críticos. Ao destituírem os valores éticos, estéticos e religiosos da sociedade capitalista, no lugar deles erigiram um altar à linguagem, fundando, assim, uma espécie de "religião estética". Só que uma religião feita de deuses ausentes e corroída pela crítica que faz de si mesma. Não obstante, é assim que ela afirma o seu poder transformador, já que, como assegurou Barthes, "politicamente, é ao professar e ao ilustrar que nenhuma linguagem é inocente, que a literatura é revolucionária"'?

3

Os escritos críticos em prosa também foram e continuam sendo exercidos sem parcimônia pelos poetas da reflexão. O ensaio é a forma privilegiada por eles, não só pela sua brevidade flexível, mas também por admitir o jogo entre subjetividade e objetividade, rigor e liberdade criativa. Tanto o ensaio entendido como forma artística, defendido por Schlegel e evocado por Lukács em carta a Leo Popper ${ }^{13}$, quanto o ensaio menos literário, "despido de aparência estética", porém assistemático e deshierarquizante, tal como o formulou Adorno ${ }^{14}$, foram praticados pelos poetas. Em alguns, a poeticidade se faz presente de forma explícita, como é o caso de Octavio Paz, que dialetizou no texto ensaístico a transitividade e a intransitividade da linguagem, não dissociando o trabalho de construção da escrita e o caráter informativo dos enunciados.

A diluição das fronteiras entre os gêneros literários, promovida pelos românticos e consumada no século $\mathrm{XX}$, possibilitou a mesclagem de diferentes tipos de discursos, entre eles, o científico e o literário. Assim como os poetas incorporaram ao seu trabalho poético o ofício crítico, muitos levando para este procedimentos usados naquele e vice-versa, alguns críticos também passaram a incorporar à escrita ensaística recursos literários cocição. Do que surgiu, ao lado da extraídos tanto da poesia quanto da fiç̧áo. Leyla Perrone, na esteira de Barthes, nomeou de crítica-escritura. Esta, uma modalidade discursiva

12. BARTHES, 1988, p.25

13. LUKÁCS OpUd ADORNO, 1986. p. 169

14. ADORNO. 0 ensaio camo forma, p.169 ambígua, espaço onde linguagem e metalinguagem se superpõem. E que, nestas últimas décadas do século XX, tem contagiado inclusive parte da produção crítica acadêmica, tendo em vista a adesão desta aos vôos da criatividade.

Essa prática híbrida, como era de se esperar, não deixou de afrontar um certo tipo de crítica tradicional, avessa à conjunção de crítica e criação em um texto que se proponha a dissertar sobre questóes literárias.

René Wellek, por exemplo, usou a palavra "falácia" para designar a crítica criadora defendida por Schlegel. ${ }^{15}$ Northrop Frye, por sua vez, afirmou ironicamente que "o poeta, falando como crítico, produz não crítica, mas documentos a serem examinados por críticos". E ainda advertiu: "Bem podem ser documentos valiosos: apenas quando aceitos como diretivos para a crítica correm algum perigo de tornar-se desencaminhadores". ${ }^{16}$

Albert Thibaudet, mais flexível, admitiu, conforme assinala Leyla Perrone, que "a crítica tem um elemento de criação, mas não pode nem deve aspirar a ser criação pura, porque o objetivo do crítico é a verdade (..) e seu discurso tem um dever de verificabilidade". ${ }^{17}$

Essas citaçōes são suficientes para que se evidencie a resistência da crítica convencional (ainda que ela integre nomes de pensadores respeitáveis que são também notáveis estilistas, como o próprio Thibaudet) ao texto crítico de ruptura que, na forma artística do ensaio, mobilizou escritores-críticos modernos e contemporâneos.

Não obstante o ensaio se afigure como a forma privilegiada por esses autores, as outras modalidades de escrita, como o fragmento, o manifesto, a carta e o depoimento, também têm sido usadas por eles com profusão no exercício da crítica em prosa, desde o século XVIII.

O fragmento, forma predileta dos românticos alemães, é ainda muito apreciado por escritores, críticos e filósofos contemporâneos. Enquanto escrita descontínua e descentrada, capaz de fazer coincidir o discurso e o silêncio, ele pode ser considerado o começo sempre inacabado que se multiplica e, ao mesmo tempo, se totaliza sob a forma de um "pensamento-frase". E, por isso, como elucida Barthes, é perfeitamente

\section{WELlLEK. History of modern criticism. p.8.}

16. FRYE, 1957. p. 14.

17. PERRONE-MOISÉS, 1978. p.7B. 
comparável à idéia musical de um ciclo: "cada peça se basta, e no entanto ela nunca é mais do que o interstício de suas vizinhas: a obra é feita somente de páginas avulsas". ${ }^{18}$

Nesse sentido, é a escrita que mais se aproxima do poema, e talvez por isso tenha seduzido poetas-críticos como Valéry, que em seus Cahiers, espécie de "antidiário de antimemórias" como bem os caracterizou Augusto de Campos, exerceu com intensidade a crítica fragmentária sobre vários temas, em diferentes campos do saber.

O manifesto, como se sabe, foi o veículo principal das propostas estéticas das vanguardas. De caráter esquemático e programático, marcado por uma forte coloração agressiva, ele resume as formulações inovadoras dos grupos vanguardistas, além de se colocar, conforme apontou Philadelpho Menezes, "como elemento em si bélico que enfrenta o resto da produção cultural e, principalmente, a tradição, guardando em regra um tom provocatório". 19

As cartas e depoimentos (aqui podem ser incluídas as entrevistas) também foram e são exercitados como atividade crítica. Só que, à diferença dos outros textos, têm uma marca mais explicitamente subjetiva, sem contudo se furtarem à reflexão e ao rigor estético. $\mathrm{E}$, no caso da carta, a presença do interlocutor implica, algumas vezes, uma discussão, principalmente quando esse interlocutor também exerce atividade poética e crítica, o que podemos atestar lendo a correspondência trocada entre Octavio Paz e Haroldo de Campos, publicada em Transblanco.

Isso não significa, entretanto, que essa modalidade textual seja necessariamente subordinada à existência de um receptor específico e nomeado, haja vista que ela pode ser um artifício de escrita e se dirigir aos leitores em geral, como as 27 cartas de Schiller, reunidas em $A$ educação estética do homem, nas quais o autor se propõe a nos expor - tomado por um “impulso lúdico" - os resultados de suas "investigações sobre o belo e a arte"20.

Além dessas formas, encontramos ainda na história da crítica feita por poetas a autobiografia crítica. É o caso da Biographia literaria, de Coleridge, onde, sob a máscara do memorialismo, o poeta discorre em ritmo de ensaio sobre literatura, política, religião e filosofia. $O$ próprio poeta admite, no primeiro capítulo, que só uma pequena parte do escrito

18. BARTHES, 1977. p.102

19. MENEZES, 1984. p.87.

20. SCHILLR, 1990. p.23 tem a ver com sua vida pessoal. E justifica: "utilizei o relato biográfico com o propósito de dar um fio condutor à obra, e em parte também pelas diversas reflexöes em mim suscitadas por eventos particulares".21 A memória, no texto, funciona menos como presentificação de vivências do que como detonadora de reflexões críticas sobre autores, obras e idéias Mas, ao mesmo tempo, propicia ao leitor a oportunidade de conhecer as preferências, as idiossincrasias e os valores literários que marcaram o trajeto intelectual e poético do escritor.

A esses textos críticos em prosa, que acompanham ou prolongam as obras poéticas de seus autores, é comumente atribuída uma função de espelho. Através deles, o poeta desenvolve o seu conceito de poesia, justifica a sua própria criação e lê - movido pelo duplo intento de se auto-alimentar poeticamente e definir a própria tradição a que pertence - obras de outros poetas - antigos ou contemporâneos.

Friedrich Schlegel foi o primeiro a mencionar o caráter especular da crítica feita pelos poetas, ao outorgar à poesia o poder de "nas asas da reflexão poética, potencializando incessantemente essa reflexão, multiplicála, como numa sucessão infinita de espelhos".22

Octavio $\mathrm{Paz}$ também referiu-se a essa dimensão especular - só que, à diferença do poeta alemão, reportando-se diretamente à relação entre ensaio crítico e obra poética - ao comentar, em entrevista, os motivos que o levaram a escrever El arco y la lira:

Escrebi El arco y la lira como una suerte de Defensa de la Poesia, a la manera de Shelley. Desde fines del siglo XVIII los poetas sintieron la necessidad de justificar con escritos en prosa la existencia de la poesía y así justificar la propia. La edad moderna ha sido la edad de la prosa y de la crítica. La prosa se convirtió en el espejo de espejo crítico, reflexivo. Los enayos un romanticismo a nuestros días, han sido la respuesta a la doble pregunta que nos hace la modernidad: ¿por qué y para qué hay poesía? Mi ibro fue una teoría. Tal vez no fue sino una imagen o, más exactamente, ese anojo de reflejos y reflexiones en que se transforma un cuerpo al refejarse en un espejo. ${ }^{23}$

Sem dúvida, uma das diferenças capitais entre os textos críticos escritos pelos poetas e os de críticos que não exercem atividades poéticas

21. COLERIDGE, 1978. p.432.

22. SCHLEGEL In: CHIAMPI, 1992. p.56

23. PAZ, 1992, p. 139. 
recai precisamente aí, nesse ponto em que teoria e prática se espelham, se elucidam, dialogam e, em muitos casos, se misturam.

$\hat{E}$ interessante observar que muitos foram os poetas que justificaram a sua condição de críticos através da desqualificação da crítica tradicional, entendida como uma forma parasitária da literatura. Para eles, a legítima crítica sobre a poesia só é aceitável se feita por quem conhece experimenta os mecanismos da construção poética, isto é, cabe ao crítico saber fazer o que examina.

$\mathrm{Na}$ esteira dessa "crítica anticrítica", Novalis, por exemplo, assegurava que "a genuína crítica requer a aptidão de produzir por si mesma o produto a ser criticado" 24 .

Essa postura, que hoje não deixa de ser questionável, indicia o caráter defensivo de alguns poetas em relação ao seu ofício de criador, num momento em que a crítica se moldava pela fôrma do cientificismo e aos críticos ortodoxos da razão era ainda atribuída a prática esterilizadora do vampirismo literário.

Movidos pelo interesse de fundar seus próprios valores e proscrever a visão crítica tradicional, os poetas se empenharam em criar uma nova concepção de crítica literária, elaborando - cada um à sua maneira, mas dialogando com os seus precursores - teorias críticas que se prestam a falar de si mesmas.

Paul Valéry, por exemplo, leitor e discípulo de Mallarmé, pode ser considerado, dentre os poetas críticos franceses do início do século, o que talvez mais tenha primado pelo rigor. Adotando uma concepção excessivamente lúcida do fazer poético, não poderia deixar de conceber a crítica como uma prática sobretudo intelectual. A idéia de que o ensaio teórico é um espelho do fazer e de que os poetas da lucidez são os mais autorizados a realizá-lo encontra nele seu maior defensor.

Isso se verifica quando o poeta, em um dos fragmentos dos Cahiers, assegura: “em mim, o crítico está sempre ocupado com o fazer.
Assumo a posição de autor para julgar uma obra. ${ }^{25}$ " Ou neste, do ensaio "O homem e a concha": "explicar nunca é mais que descrever uma maneira de fazer: é apenas refazer através do pensamento"26.

À imagem do poeta que, através do pensamento levado às últimas conseqüências, se volta criticamente sobre si mesmo, Valéry associa a figura da serpente que devora a própria cauda, conhecida miticamente como uroboros. Conforme argumenta Augusto de Campos, “a serpente é, acima de tudo, na simbólica valéryana, o ícone do pensar - uma atividade que ele tentou conduzir aos limites extremos". Tão extremos que, para ele, a finalidade de uma obra não é mais nem menos que, mesmo a contragosto, fazer pensar o leitor.

A metáfora da serpente que se autodevora, recorrente em toda a obra do poeta, pode, com justeza, prestar-se à caracterização da atividade crítica dos demais poetas-críticos. Mesmo que nem todos sejam adeptos tão fervorosos da "religião do esmero", o fato de se voltarem reflexivamente sobre a própria criação é suficiente para que sejam igualmente emblematizados pela figura narcísica e paradoxal da serpente valéryana.

Outro poeta que se dedicou a elaborar exaustivamente uma teoria da crítica foi Eliot. Autor de inúmeros ensaios sobre assuntos diversificados no campo da literatura, da cultura e da política, destaca-se ele, ao lado de Ezra Pound, como um dos mais expressivos e polêmicos poetas-críticos anglo-americanos, desde Edgar Allan Poe.

Aquiescente com alguns princípios poéticos advogados por Valéry, Eliot também atesta o caráter absolutamente estético e impessoal da obra poética, onde, sob sua ótica, não há espaço para o sentimento do poeta. Uma de suas sentenças mais peremptórias diz que "a poesia não é uma liberação da emoção, mas uma fuga da emoção"27, o que pode ser também aplicado ao exercício crítico.

Quase todos os ensaios que escreveu sobre a crítica confirmam a idéia já antes propagada pelos românticos alemães e endossada por Valéry de que a crítica de poesia é ofício a ser exercido por poetas. Em "The function of the criticism"(1923), por exemplo, ele sustenta: "a crítica utilizada por um escritor hábil e experimentado em sua própria obra é a mais vital, a mais alta espécie de crítica; e (como penso já ter dito antes) os

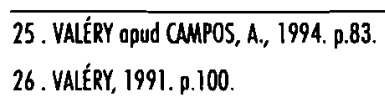


escritores criativos são superiores a outros unicamente porque sua faculdade crítica é superior" ${ }^{28}$.

Para Eliot, a possibilidade de se fundir criação com crítica aponta também para a pertinência de se conjugar a crítica com a criação, do que resultaria a crítica-criativa ou, como ele preferia dizer, a "crítica de oficina", cujas qualidades foram ostensivamente relevadas por Pound em seus escritos teóricos, já que, também para este, a crítica precisa exercer uma "função vivificadora" com relação à criação e vice-versa. Pound, cuja inquietação teórica o incitou a privilegiar o novo como critério de avaliação poética, revitalizou o método científico de investigação literária através do lema "make it new". Ao adotar o chamado método crítico ideogramático (fundamentado nos princípios da escrita chinesa) e ao transformar a tradução numa modalidade de crítica-criativa, o mestre de Eliot deu um salto em relação às teorias da crítica até então existentes, abrindo caminho para que poetas posteriores pudessem reelaborar e desenvolver essas vias criativas da crítica, principalmente a da tradução.

É curioso que a crítica-criativa tenha sido revista e questionada mais tarde por Eliot, em ensaio de 1956. Embora ressaltando as qualidades dessa "crítica de oficina", e reconhecendo que o melhor da sua própria produção consistiu em ensaios sobre poetas e obras que o motivaram literariamente, o poeta chama a atenção para uma limitação, segundo ele, óbvia, a ela inerente: a auto-referencialidade. Eliot afirma que, a propósito desse tipo de texto, "o que não tem nenhuma relação com a obra do próprio poeta ou lhe é antipática fica fora de sua competência" ${ }^{29}$. Com isso enfatiza e discute, ao mesmo tempo, o critério valor que mobiliza a escolha poética dos poetas-críticos. Valor que, nas teorias de Ezra Pound, se explicita de forma radical quando este cria a sua paideuma e diz que "a excelência de um crítico se mede não por sua argumentação, mas pela qualidade de sua escolha" $"$.

Mais uma vez emerge aqui a instigante imagem da serpente valéryana. Observe-se que, mesmo os poetas refratários às expressões da subjetividade e adeptos do rigor intelectual, acabam se rendendo aos encantos da própria lucidez e monumentalizando o ofício narcísico da auto-devoração. Isso advém, como apontou Octavio Paz, da "paixão crítica" desses autores pela atividade poético-crítica que exercitam: "amor

28. E.L10T, 1975. p.73

29. EL10T, 1986. p. 107

30. POUND opud. CAMPOS, 1993. p.17-18. inmoderado, pasional, por la crítica y sus precisos mecanismos de desconstrucción, pero también crítica enamorada de su objeto, crítica apasionada por aquello mismo que niega"3!. Sem dúvida, um caso de amor, em que o objeto amoroso seduz tanto pelo que é quanto pela parte em que nele se vê o desejo do poeta.

5

Leyla Perrone-Moisés, em trabalho precursor sobre a produção crítica dos escritores $^{32}$, atribui à precariedade de valores estáveis da crítica tradicional o motivo principal da irrupção desse novo tipo de texto, onde crítica e criação vivem em contínuo diálogo. Para ela, "desde que as Academias se calaram e as obras cessaram de nascer no horizonte confortável de uma expectativa (código moral, código de gêneros, código de estilos), os escritores parecem ter sentido a necessidade de dar a eles mesmos suas razões para escrever, e as razōes de o fazer de determinado modo". ${ }^{33}$

Como vimos, a presença de valores bem definidos nos textos críticos de criadores é inegável. A leitura que esses autores fazem da própria obra e de obras alheias obedece - em sua maioria - a critérios subjetivos, como o conceito de poesia que defendem e a linhagem poética a que se filiam. Eles levam às últimas conseqüências a máxima de Valéry segundo a qual "lire c'est élire".

Como esclarece Leyla, a crítica arquitetada por eles, além de ser a mais investida, por orientar a produção artística que desenvolvem, pode ser tomada como uma forma de reescritura da história literária. Eles assumem, ao elegerem obras, autores e épocas que possam nutri-los poeticamente, a tarefa de traçarem a sua própria tradição.

Partindo da análise da produção crítica de vários escritores deste século, entre eles os poetas Eliot, Pound, Borges, Paz e Haroldo de Campos, Leyla observa que - a despeito das diferenças que particularizam cada um - todos apresentam, além do forte caráter valorativo de suas reflexōes, uma

\section{PAZ, 1989. p.21-23.}

32. O relerida trabalho desdobra-se em três textas publicados em três números da revisto Colóquio- Letros, nos anos de 1982, 1984

33. PERRONE-MOISÉS, 1982. p.7. 
concepção sincrônica do tempo. Ou seja, como grandes leitores que são, esses escritores revêem e escolhem os seus precursores sob a ótica do presente, criando uma história literária fundada não mais na idéia de evolução e continuidade, mas na visão simultaneísta de tempos e espaços.

Leyla Perrone ainda enfatiza que todo esse movimento de leitura do passado é empreendida pelos escritores com vistas a uma práxis, ou seja, a própria criação, e acrescenta:

Ler é dar sentido, sincronizar, vivificar, escolher e apontar valores. A leitura ativa é construtiva, porque ela determina e justifica os rumos do futuro, e é destrutiva, porque ultrapassa as regras de medida vigentes. Viva, e por isso arriscada, a história sincrônica dos escritores-críticos é um julgamento interessado. Em suas teorizaçōes, eles pertencem àquela categoria que Nietzsche chamava de "filósofos do perigoso', aqueles que não aceitam tábuas previamente ordenadas e se aventuram na invenção de uma nova ordem. ${ }^{34}$

A questão da sincronia merece algumas observaçōes. Ainda que esses poetas tenham postulado uma poética predominantemente sincrônica, sobretudo Pound, que explicitou e radicalizou teoricamente a sua opção, poetas como Haroldo de Campos e Octavio Paz não tratam diacronia e sincronia em termos excludentes.

Apoiados nas teorias formalistas de Jakobson e Tynianov, que dialetizam a relação entre as duas concepções de tempo, eles privilegiaram a sincronia, mas com o cuidado de não perderem o senso da historicidade. Quando Haroldo de Campos lê Sousândrade à luz das poéticas de vanguarda ou Paz recupera a obra barroca de Sór Juana Inês de la Cruz pelo viés da poesia moderna, eles fazem o corte sincrônico do passado, sem contudo deixar de considerar o contexto e a tradição literária predominantes nas épocas enfocadas. Ambos reconhecem que a sincronia pura é uma ilusão, não podendo mais ser tratada a não ser em termos de complementariedade com a diacronia. Sob esse prisma, assim como na abordagem histórica existe sempre um elemento sincrônico nela incrustrado, o quadro sincrônico também é "historicizado", "embebido em diacronia, embutido na tradição". 35

Haroldo de Campos vem explicitando essa posição em vários textos, não deixando, entretanto, de demonstrar a sua preferência estética pela concepção sincrônica. Em entrevista, onde defende uma visão dialética entre passado e presente, o poeta-crítico reafirma: "gosto de ler a tradição como uma partitura transtemporal, fazendo, a cada momento, 'harmonizaçōes' síncrono-diacrônicas, traduzindo, por assim dizer, o passado de cultura em presente de criaçāo"36.

Assim, pode-se dizer que se os poetas, à feição de Benjamin, privilegiam o tempo presente como lugar de leitura do passado, é porque acreditam que "arrisca-se a tornar-se irrecuperável, desaparecer, toda imagem do passado que não se deixe reconhecer como significativa pelo presente" ${ }^{37}$. O que não significa, necessariamente, que eles sustentem uma visão a-histórica da arte e da literatura.

Octavio Paz, por exemplo, embora afirme o caráter permanente da poesia, não deixa de dialetizar a relação entre o poético e o histórico: para ele, a poesia afirma e nega a história ao mesmo tempo, ou seja, ela se encarna na história na mesma medida em que a transcende. Conforme observou lucidamente Sebastiāo Uchoa Leite, $\mathrm{Paz}$ tanto diacroniza o poético ao "perceber as significações históricas de cada poema", como sincroniza a história, ao sustentar o caráter único da criação ${ }^{38}$. E é a partir dessa dialética que o poeta mexicano refuga a idéia de a obra ser um documento social, já que, como criação verbal, um texto literário - mesmo tendo marcas de uma determinada época - sobreexiste à história: toda obra literária está inscrita na história, por ser datada, mas desta se desprende, no momento em que é lida de modo diferente em épocas distintas. A leitura, como prática de recriação, faz com que a obra seja repetida e transformada sucessivamente ao longo dos tempos.

Retomando as reflexões suscitadas pelos apontamentos de Leyla Perrone, vale dizer que os poetas-críticos, com o propósito tanto de orientar teoricamente a sua práxis poética quanto de desafiar a crítica tradicional, fundaram uma nova abordagem da história literária, sustentada na idéia de invenção e que consiste hoje numa das mais poderosas vertentes da crítica contemporânea.

Pode-se inclusive afirmar, com Rodríguez Monegal, que a crítica atual "é, na maior parte, uma discussão do que os praticantes disseram sobre a poesia própria e alheia" ${ }^{39}$.

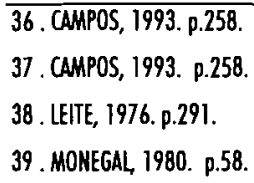

39. MONEGAL, 1980. p.58. 
Os poetas que pensaram a poesia e a história ao longo da Modernidade ofereceram os elementos para que os desta segunda metade do século XX pudessem revisar e compreender a complexidade que marcou as artes dos dois últimos séculos no Ocidente. Não é impróprio afirmar que os poetas-críticos foram os primeiros a teorizar literariamente a Modernidade. Temos, como precursor exemplar, Baudelaire, o crítico de Le Peintre de la Vie Moderne, que foi, provavelmente, o primeiro a usar e a conceituar a palavra "modernidade" no âmbito estético, além de ter sido também o primeiro a escrever criticamente sobre a relação conflituosa do poeta moderno com os avanços do capitalismo nos grandes centros urbanos do final do século XIX.

De Baudelaire a nossos dias, coube especialmente aos poetas que o sucederam o trabalho arqueológico de decifração dos signos da poesia e da história da tradição moderna. Do que resultaram nada menos que uma outra poética, uma outra lógica e uma outra concepção de história que em meio à profusão atual de linhas teóricas - têm mobilizado muitos estudos na área de Literatura Comparada.

Um outro aspecto relevante na história ocidental da conjunção poesia-crítica, que mostra a disseminação criativa dessa prática em outras paragens que não os territórios europeu e norte-americano, diz respeito ao fato de que a América Latina tenha sido, principalmente ao longo deste século, o reduto de alguns dos mais ilustres representantes dessa linhagem. Escritores como os hispano-americanos Jorge Luis Borges, Julio Cortázar, Alfonso Reyes, Lezama Lima, Octavio Paz, Severo Sarduy e os brasileiros Mário e Oswald de Andrade, Murilo Mendes, João Cabral de Melo Neto, Haroldo e Augusto de Campos, Afonso Ávila, dentre outros, repensaram crítica e literariamente a arte e a literatura de seu tempo e de seu país, conjugando-as com a cultura universal. Cosmopolitas, poliglotas e enciclopédicos, poetas-críticos como Jorge Luis Borges e Octavio Paz transcenderam os limites geográficos e culturais de seus respectivos territórios e notabilizaram-se no mundo como escritores de âmbito universal. Conforme aponta Rodríguez Monegal, "os nomes de Paz e de Borges converteram-se em cifra (ou símbolo) de uma maneira de ler da cultura contemporânea ${ }^{\text {10 }}$, interferindo ativamente na produção literária e teórica dos países do chamado primeiro mundo.

Só que, à diferença de outros poetas-críticos europeus e norteamericanos, os latino-americanos falam a partir da sua condição cultural

40. MOHEGAL 1980. p.46 periférica, e, por isso mesmo, problematizam mais as contradições de sua própria história cultural em relação à de outras tradições. Ao mesmo tempo em que continuam o trabalho crítico e poético de seus precursores estrangeiros, os nossos poetas-críticos o reavaliam dentro de um outro contexto e de uma nova postura frente à história e à tradição. Movidos por uma "razão antropofágica"4l, sustentam uma postura dialógica frente ao embate da cultura latino-americana com o legado europeu, sem sucumbirem à estreiteza da xenofobia ou à humilhação do simulacro. Dentro desse prisma, se as literaturas periféricas se nutriram da literatura européia, esta também passou a ser alterada por aquelas, o que desencadeou um processo de transculturação recíproca na era contemporânea.

Não é excessivo dizer que os poetas-críticos latino-americanos desta segunda metade do século têm, reconhecidamente, "buliversado" a história da poesia (e da crítica) ocidental. Não só por ampliarem as reflexões sobre a poética da leitura e da tradução iniciadas pelos seus antecedentes como também por se darem a tarefa de revisar a história da literatura moderna, a partir de uma ótica criativa e pluricultural. Borges, Paz e Haroldo de Campos, dentre outros, colocam-se sob o traço da multiplicidade, ao transformarem suas obras numa espécie de "ars combinatória" dos signos das várias tradições do Ocidente e do Oriente, que se evidencia tanto na criação literária, quanto na crítica e no exercício da tradução. Aliás, para eles, criação, crítica e tradução não se dissociam: a leitura que fazem do passado vale-se da combinação desses três elementos, já que a tradução foi convertida em crítica e recriação da tradição.

Borges repensou - sobretudo pela via ficcional - a questão do autor e do leitor. Ao "aniquilar as pretensões de paternidade literária", 42 ele privilegiou a recepção em detrimento da produção, ressaltando que o escritor é, antes de tudo, um leitor. Com isso criou uma teoria da leitura e a ela vinculou a idéia de reescritura do passado. Sob essa ótica, aboliu-se a suposta existência de um texto original, já que uma obra passou a ser a soma e a recriação de todas as leituras que o autor fez de outras obras também recriadas a partir de outras.

Nesse movimento labiríntico da intertextualidade, a tradução também é vista por Borges como leitura recriadora da tradição. Quando discorre, por exemplo, sobre as várias traduções feitas ao longo dos séculos de As Mil e uma Noites, Borges comenta que Galland, o tradutor francês da
41. CAMPOS, 1993. p.231.

42. MONEGAL, 1980. p.69. 
obra, nela insere o conto Aladim e a lâmpada maravilhosa, inexistente em outras versões. E questiona as acusações de que o tradutor teria falsificado a narrativa, afirmando que Galland tinha tanto direito de inventar um conto quanto os criadores do livro. E pergunta: “¿Por qué no suponer que después de haber traducido tantos cuentos, quiso inventar uno y lo hizo?"43

Assim como Borges, ou mesmo à luz de Borges, Octavio Paz e Haroldo de Campos enfatizaram a leitura como forma de reinvenção do passado e redimensionaram teoricamente o problema da tradução. Mais comprometidos do que o escritor argentino com os princípios poéticos das vanguardas (embora este tenha participado, num primeiro momento, do movimento das vanguardas hispano-americanas) e mais afeitos às teorias modernas e contemporâneas da linguagem, eles dialetizam a relação entre passado e presente, pelo viés da invenção. Revisando e revigorando as propriedades da tradução criativa anunciadas sobretudo por Ezra Pound e Valéry, eles colocam, em sincronia e diálogo babélico, literaturas de todas as épocas e vários lugares do mundo. Cada um, entretanto, criando uma poética específica da tradução.

Depois da breve incursão que fizemos nos textos críticos de alguns poetas-pensadores, podemos constatar que estes, embora não possam ser agrupados em um conjunto homogêneo de autores, defendem muitos pontos em comum. À parte as diferenças nacionais, a distância temporal entre eles e as peculiaridades subjetivas de cada um, é possível indicar um rol mais ou menos coerente de princípios por eles sustentados, como a defesa e a supervalorizaçāo da poesia (tomada como uma espécie de "religião estética"), a negação de procedimentos críticos tradicionais, a conquista da universalidade, a adoção da visão simultaneísta do tempo, a ênfase na leitura e na tradução como vias para se reler a história da poesia moderna e a reflexāo sobre o conflito tradição/modernidade; estes dois últimos evidenciados a partir do início do século $\mathrm{XX}$.

Todos esses traços podem, de certa maneira, caracterizar (mas não delimitar) o viés crítico dos poetas modernos e contemporâneos, e se, tomados em conjunto, podem também diferenciá-lo da crítica praticada pelos não poetas.

43. BORGES, 1989. p. 240 .
Isso não significa, porém, que os poetas-críticos tenham prescindido dos instrumentais teóricos também oferecidos por algumas correntes da crítica moderna, como o formalismo, o estruturalismo, a semiologia e os diferentes ramos da semiótica, que, por sua vez, igualmente se viabilizaram a partir do advento da arte moderna. Dentre essas linhas, podemos destacar o formalismo, a que estiveram ligados poeticamente Maiakóvski, Khliébnikov e Assiéiev, e que não apenas acompanhou ou orientou as idéias inovadoras do futurismo russo, como também abasteceu teoricamente muitos poetas-críticos da segunda metade do século XX.

Enfim, pode-se dizer que todos os poetas-críticos, do romantismo alemão até hoje, não deixaram de fazer da lucidez a sua própria vertigem.

REFEREACIAS BIBLIOGRÁFICAS

ADORHO, Theodor W. O ensoio coma formo. In: COHN, Gobriel.(org.) Coleç̃o Grondes Cientistos Sociais. Sõo Poulo: Atico, n. 54, 1986

BARTHES, Roland. Crftico e verdade. Trad. Geroldo Gerson de Sausa. Söo Paulo: Perspectiva, 1982

- Roland Barthes por Roland Barthes. Trad. Leylo Perrone. Sóo Poulo: Culthix. 1977

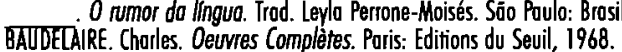

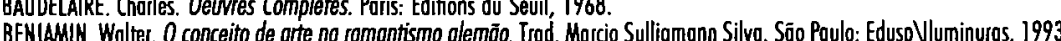

BLANCHOT. O "Athenaeum". Trod. Bernorda Carvalho. Folha de Säa Poulo, Säo Poulo, 27 moi. 1988. Folhetim.

O espaco liferório. Trod. Álvaro Cabral, Rio de Janeiro: Rocco, 1987.

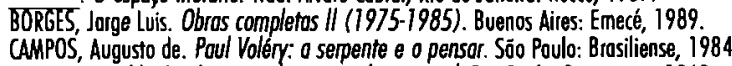

CAMPOS, Haroldo de. A arte no horizonte do provóvel. Söo Paulo: Perspectivo, 1969.

Metalinguogem e outros metos. Sōo Poulo: Perspectiva, 1993.

CAMPOS, Haroldo de. Poesio y modernidod. Wuelto. México, a. 99 , feb. 1985.

CHIAMPI, Irlemar (org.). Fundodores do modemidode. Sóo Paulo: Alico, 1992

COLERIDGE. The portoble Coleridge. Selers̄o 1.A. Richards. New Yark: Penguin Books, 1978.

ELLTT. On poetry ond paets. London: Fober \& Fober, 1986.

Torthrop. Anotomy of criticism. Princeton University Press: 1957.

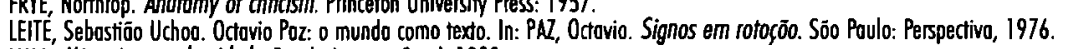

LEIIE, Sebastiüo Uchoo. Octavio Poz: O mundo como texto.

MALLARMÉ. Un coup de dés jomois n'oboliro: le hasard. Sóo Poulo: Perspectiva, 1980. (sepasota do livro Mallorme, orgonizodo por

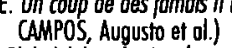

MENEZES, Philadelpho. A crise do possodo. São Poulo: Experimento, 1994

MONEGAL, Emir R. Borges e Poz: un diálogo de textos crificos. Borges: uma poefica da leitura. Trod. Irlemar Chiompi. Söo Puulo: Perspectiva, 1980. 
NOVALLS. Pólen. Trod. Rubens Torre Filho. Sõo Poulo, lluminuras, 1988.

PAZ. Convergencias. Mexico: Seix Boural, 1992. (10 edicōo: 1991)

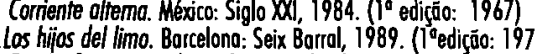

re CampOS, haroldo. Transblenco. Soo Paulo: Siciliano, 1994.

PERRONE-MOISES. Escolher e/e jugor. Cologuio- Lemos. Lisbaa, n.65, jon. 1982

Colbuio Lef us lisboo, n. 77 , jon. 198

Historio literória e julgamenta de vajor Il. Coloquio-letros. lisboo: n.100, nov/dez. 1987.

Texto, crifica, escrituro. Soo Pavio: Aico, 1978

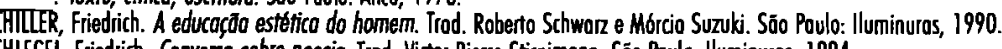

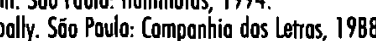

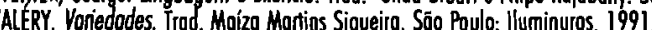

WELLEK, René. History of modem criticism. London: Jonothon

Cope, v.2, 1955

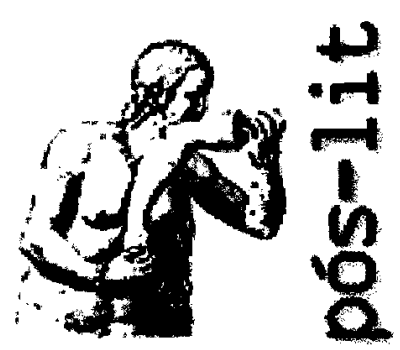

Programa de Pós-Graduação em Letras: Estudos Literários da Faculdade de Letras da UFMG

Artigo disponível em

http://www.letras.ufmg.br/poslit 